\title{
Doppler Evaluation of Homograft Valved Conduits in Children
}

Jon N. Meliones, MD, A. Rebecca Snider, MD, Edward L. Bove, MD, Gerald A. Serwer, MD, Jane Peters, Samuel J. Lacina, MD, Michael S. Florentine, MD, and Amnon Rosenthal, MD

\begin{abstract}
To assess the flow characteristics of homograft valved condults in the immediate postoperative period, 69 children with 71 homograft condults underwent 2-dimensional and Doppler echocardiographic examination at 1 to $\mathbf{4 0}$ days (mean 8) after surgery. Of the 71 conduits studied, 19 were aortic and $\mathbf{5 2}$ were pulmonary homograft valved condults. Two aortic homograft valved condults were inserted in the aortic position, whereas all remaining homografts were placed in the pulmonary position. On the immediate postoperative echocardiogram, $25(35 \%)$ of the condult valves had no regurgitation and $44(62 \%)$ had $1+$ (mild) regurgitation. Two pulmonary valved conduits $(3 \%)$ in the pulmonary postion had $2+$ (moderate) regurgitation and ingt ventricular dimensions $>95 \%$ for body surface area. The peak velocity across the homograft valve was normal $(<1.3 \mathrm{~m} / \mathrm{s})$ in 58 valves $(82 \%)$. In the remaining 13 valves, peak velocity ranged from 1.4 to $2.6 \mathrm{~m} / \mathrm{s}$. No homograft valve had a peak velocity $>2.6 \mathrm{~m} / \mathrm{s}$ in the immediate postoperative pe. riod.
\end{abstract}

To assess the fate of homograft valved conduits in the intermediate-term follow-up period, 38 children with 38 conduits had a repeat echocardiogram at 6 to 25 months (mean $15 \pm 6$ ) after surgery. Of the 38 conduits examined, $10(26 \%)$ had no regurgitation, $25(66 \%)$ had $1+$ regurgitation and 3 (8\%) had 2+ regurgitation. Progression of the amount of regurgitation occurred in 11 (29\%) patients.

At the follow-up examination, peak velocity was $\leq 1.4 \mathrm{~m} / \mathrm{s}$ across 34 conduit valves, between 1.4 and $2.6 \mathrm{~m} / \mathrm{s}$ across 3 valves and $>2.6 \mathrm{~m} / \mathrm{s}$ across 1 valve. This latter patient had a $3.2-\mathrm{m} / \mathrm{s}$ jet across the proximal insertion of the conduit and no further increase across the valve itsolf. Thus, no patient had evidence of conduit valve stenosis. Of the 38 patients, 9 had Doppler evidence of obstruction at the conduit insertion (8 at the distal end and 1 with the aforementioned proximal obstruction). Most obstructions were of mild to moderate severity and only 2 patients (5\%) had severe conduit stenosis.

Thus, in the immediate postoperative period, normally functioning homograft valved conduits frequently have mild regurgitation (62\%) and rareIy have moderate or severe regurgitation $(3 \%)$, with peak velocities reaching $<2.6 \mathrm{~m} / \mathrm{s}$. In the in- patients, 9 had Doppler evidence of obstruction at the condult Insertion (8 at the distal end and 1 with the aforementioned proximal obstruction). Most obstructions were of mild to moderate severity and only 2 patients (5\%) had severe conduit stenosis.

Thus, in the immediate postoperative period, normally functioning homograft valved condults frequently have mild regurgitation $(62 \%)$ and rareIy have moderate or severe regurgitation (3\%), with peak velocities reaching $<2.6 \mathrm{~m} / \mathrm{s}$. in the intermediate follow-up period, homograft valved conduits may develop an additional degree of regurgltation (29\%), frequently continue to have conduit peak velocities $<2.6 \mathrm{~m} / \mathrm{s}(97 \%)$ and uncommonly develop hemodynamically significant obstruction, usually at the ends of the conduit (5\%).

(Am J Cardiol 1989;64:354-358)

I $\mathrm{n}$ infants and children with congenital heart disease, valved conduits are widely used, especially for the repair of defects with right ventricular-pulmonary artery discontinuity. In 1966, Ross and Somerville ${ }^{1}$ introduced the use of fresh aortic homograft valved conduits; however, because of problems with limited availability and early calcification of these irradiated conduits, alternative valved conduits were sought. ${ }^{2,3}$ In 1973 , the use of a porcine heterograft valve mounted in a woven Dacron tube was proposed, ${ }^{4}$ and, because of its ready availability, it soon became the most widely used conduit. ${ }^{5,6}$ Long-term follow-up studies of children with heterograft porcine valved conduits showed, however, a disappointing rate of development of obstruction at the porcine valve and in the Dacron conduit itself..$^{7-10}$ As a result of these studies and because of the development of improved techniques for preparation and preservation of homograft valves, antibiotic-sterilized homograft valves are now being widely used in children and are favored by most surgeons because of their lower antigenicity compared with porcine valved conduits. ${ }^{11-20}$

From the Departments of Pediatrics and Surgery, C.S. Mott Children's Hospital, University of Michigan Medical Center, Ann Arbor, and Butterworth Hospital, Grand Rapids. Michigan. Manuscript received February 6, 1989; revised manuscript received May 4, 1989, and accepted May 5.

Address for reprints: A. Rebecca Snider, MD, Division of Pediatric Cardiology, Room F1115, Box 0204, C.S. Mott Children's Hospital, Ann Arbor, Michigan 48109-0204. 
The continuing search for the optimal extracardiac conduit requires accurate information on the long-term fate of these conduits. Although the Doppler flow characteristics of normally functioning and malfunctioning mechanical and heterograft prosthetic valves have been well described, ${ }^{21-29}$ there are no descriptions of the Doppler flow characteristics of the normally-functioning homograft valve in the immediate postoperative period. The purposes of this study were to determine the characteristics of flow through the normally functioning homograft valved conduit in the immediate postoperative period using Doppler echocardiography and to evaluate the fate of these conduits at the intermediate postoperative follow-up echocardiographic examination.

\section{METHODS}

Patients: From September 1985 to October 1988, 74 homograft valved conduits were placed in 72 children ( 2 children had 2 homograft valved conduits each). Sixty-nine of the 72 children underwent 2-dimensional and Doppler echocardiographic examination in the immediate postoperative period. Three patients died before a postoperative echocardiographic examination could be performed. The study group comprised the 69 surviving children, who had a total of 71 homograft valved conduits. Their diagnoses are listed in Table $\mathrm{I}$.

The study group included 35 girls and 34 boys. Age at operation ranged from 1 day to 40 years (mean \pm standard deviation $5.8 \pm 2.0$ years). Eight patients were $<1$ month old, 6 were 1 month to 2 years old, 32 were 2 to 6 years old and 23 were $>6$ years old. Their weight at operation ranged from 2 to $96 \mathrm{~kg}$ (mean $21.6 \pm 4.0$ ).

Homograft valves: Of the 71 homograft valved conduits studied, 19 were aortic and 52 were pulmonary homograft valves. All pulmonary homograft valves were inserted in the pulmonary position. Seventeen aortic homograft valves were inserted into the pulmonary position and 2 were inserted into the aortic position. The valves ranged from 8 to $27 \mathrm{~mm}$ in diameter. Six valves measured between 8 and $14 \mathrm{~mm}, 18$ between 15 and 20 $\mathrm{mm}$ and 47 between 20 and $27 \mathrm{~mm}$.

Operative techniques: Cryopreserved homografts (Cryolife) were used in all patients. Valves were harvested from cadavers in whom perfusion was being maintained. The valves were cultured, sized, trimmed of excess tissue and frozen to $-197^{\circ} \mathrm{C}$ in liquid nitrogen for subsequent use. In the initial patients, aortic homografts were primarily used. In later patients, pulmonary homografts were preferred because of their thinner walls and superior suturing characteristics. Selection of homograft size was determined by patient size and graft availability. No deliberate effort was made to "oversize" the conduit for any patient. A knitted Dacron tube soaked in albumen or plasma was autoclaved to minimize bleeding and then used to lengthen the homograft proximally to provide a hood for the ventricular anastomosis. Whenever possible, the Dacron extension was sharply beveled, leaving only a $2-$ to $3-\mathrm{mm}$ rim posteriorly to reduce the circumferential Dacron to a minimum. When pulmonary artery branch stenosis was pre-

\begin{tabular}{|ll|}
\hline TABLE I Homograft Valved Conduit Patients \\
\hline \\
\hline Diagnosis & $\begin{array}{l}\text { No. of Pts } \\
(n=69)\end{array}$ \\
\hline Pulmonary atresia/VSD & 28 \\
Truncus arteriosus & 14 \\
Tetralogy of Fallot & 7 \\
D-transposition/VSD/PS & 6 \\
L-transposition/VSD/PS & 5 \\
Double outlet right venitricle /PS & 3 \\
Aortic stenosis & 2 \\
Atrioventricular septal defect/PS & 2 \\
S/P arterial switch/PS & 2 \\
\hline PS $=$ pulmonary stenosis; S/P = status postoperative, VSD = ventricular septal \\
defect.
\end{tabular}

sent, the distal end of the conduit was used as an onlay patch.

Echocardiographic examination: All 69 patients underwent a complete 2-dimensional and Doppler echocardiographic examination in the immediate postoperative period. The initial postoperative examination was obtained from 1 to 40 days (mean 8) after surgery. In addition, 38 patients (with 38 conduits) had a repeat echocardiogram in the intermediate postoperative follow-up period. The follow-up examinations were obtained from 6 to 25 months (mean $15 \pm 6$ ) after surgery. Thirteen patients were examined from 6 to 12 months after surgery and 25 were examined from 12 to 25 months after surgery.

Ventricular dimensions were measured from an $\mathrm{M}$ mode echocardiogram generated from the 2-dimensional sector scan. Homograft valve stenosis was assessed by measuring the peak flow velocity through the homograft valve from multiple transducer positions using pulsed, high-pulse repetition frequency and continuous-wave Doppler techniques. The highest value for the peak velocity was used in the simplified Bernoulli equation (gradient $=4 \times$ peak velocity ${ }^{2}$ ) to calculate the peak instantaneous pressure gradient across the homograft valve. The proximal and distal conduit insertions also were examined for evidence of obstruction.

Pulsed and color flow Doppler mapping techniques were used to detect homograft valve regurgitation. Regurgitation was diagnosed when Doppler signals arising from blood flow passing retrogradely across the valve in diastole were present. The amount of regurgitation was graded according to the following parameters: (1) mild $(1+)=$ small, narrow jet of low amplitude detected near the valve origin with normal cardiac chamber dimensions; (2) moderate $(2+)=$ easily detected, high amplitude jet associated with cardiac chamber enlargement; and (3) severe ( 3 to $4+)=$ wide, easily-detected, high amplitude jet with marked cardiac chamber enlargement and with evidence of marked diastolic runoff of blood from the aorta or pulmonary artery.

\section{RESULTS}

Immediate postoperative examination: Of the 71 conduits evaluated in the immediate postoperative period, $25(35 \%)$ had no homograft valve regurgitation, 44 


\begin{tabular}{|c|c|c|}
\hline $\begin{array}{l}\text { Amount of } \\
\text { Regurgitation at } \\
\text { Postoperative } \\
\text { Examination }\end{array}$ & $\begin{array}{l}\text { Amount of } \\
\text { Regurgitation } \\
\text { at Follow-Up } \\
\text { Examination }\end{array}$ & $\begin{array}{l}\text { No. of Pts } \\
(n=38)\end{array}$ \\
\hline 0 & 0 & 6 \\
\hline 0 & $1+$ & 8 \\
\hline 0 & $2+$ & 1 \\
\hline $1+$ & 0 & 3 \\
\hline $1+$ & $1+$ & 16 \\
\hline $1+$ & $2+$ & 2 \\
\hline $2+$ & 0 & 1 \\
\hline $2+$ & $1+$ & 1 \\
\hline $2+$ & $2+$ & 0 \\
\hline
\end{tabular}

(62\%) had $1+$ regurgitation and 2 pulmonary homograft valves in the pulmonary position $(3 \%)$ had $2+$ regurgitation. The 2 patients with $2+$ regurgitation had right ventricular diastolic dimensions $>95 \%$ for body surface area.

Evaluation of the velocity profile across the homograft valve showed a normal peak flow velocity $(<1.3$ $\mathrm{m} / \mathrm{s}$ ) across 58 valves (82\%). In the remaining 13 valves (all with 0 or $1+$ regurgitation), the peak velocity ranged from 1.4 to $2.6 \mathrm{~m} / \mathrm{s}$. No homograft valve had a peak velocity $>2.6 \mathrm{~m} / \mathrm{s}$ in the immediate postoperative period. For the entire group, the peak velocity was 1.6 $\pm 0.3 \mathrm{~m} / \mathrm{s}$. Doppler evaluation of the proximal and distal insertions of the homograft valved conduit showed no patient with obstruction at the ends of the conduit in the immediate postoperative period.

Intermediate follow-up examination: Thirty-eight patients with 38 conduits had intermediate-term followup echocardiographic examinations. Of the 38 conduits examined, $10(26 \%)$ had no regurgitation, $25(66 \%)$ had $1+$ regurgitation and $3(8 \%)$ had $2+$ regurgitation $(\mathrm{Ta}-$ ble II). No patient had $>2+$ regurgitation. Of the 10 patients with no regurgitation, 6 had no regurgitation in the immediate postoperative period, 3 had $1+$ regurgitation and 1 had $2+$ regurgitation. Of the 25 patients with $1+$ regurgitation, 8 had no regurgitation on the immediate postoperative examination, 16 had $1+$ regurgitation and 1 had $2+$ regurgitation. All 3 patients with $2+$ regurgitation had pulmonary valve conduits in the pulmonary position. Their right ventricular diastolic dimensions were larger than the $95 \%$ for body surface area. All 3 patients had an increase in the amount of regurgitation from the immediate postoperative echocardiogram. One patient had no regurgitation on the immediate postoperative echocardiogram, whereas the other 2 patients had $1+$ regurgitation in this period.

At the follow-up examination, the peak flow velocity was $\leq 1.4 \mathrm{~m} / \mathrm{s}$ across 34 conduit valves, it ranged between 1.4 and $2.6 \mathrm{~m} / \mathrm{s}$ across 3 valves, and was $>2.6$ $\mathrm{m} / \mathrm{s}$ across 1 valve. One patient with a 14-mm Hg peak gradient across the conduit valve $(1.9 \mathrm{~m} / \mathrm{s})$ had a predicted right ventricular systolic pressure of $74 \mathrm{~mm} \mathrm{Hg}$ (predicted by Doppler from the tricuspid regurgitation jet). This finding suggested severe distal conduit stenosis; however, due to limited echocardiographic access, the distal conduit insertion could not be examined directly with Doppler echocardiography. At catheterization, this patient had severe stenosis at the distal insertion of the conduit and no gradient across the conduit valve. No other patient had evidence of unexplained right ventricular hypertension in the face of normal peak flow velocity across the conduit valve. One patient with a peak velocity of $3.2 \mathrm{~m} / \mathrm{s}$ across the conduit valve had a $3.2-\mathrm{m} / \mathrm{s}$ jet across the proximal insertion of the conduit. In this patient, the increased velocity across the conduit valve was due to the persistence of a high-velocity jet originating at the proximal obstruction (pulsed Doppler examination showed no further increase in peak flow velocity across the valve itself). Evidence of obstruction at the proximal or distal conduit insertions was found in 9 patients at the intermediate follow-up examination (Table III). The peak velocity across the obstruction in these patients ranged from 2.0 to $4.0 \mathrm{~m} /$ s. One patient with truncus arteriosus had a $64-\mathrm{mm} \mathrm{Hg}$ gradient across the distal conduit insertion. The conduit valve in this patient appeared normal and had a peak flow velocity of $1.5 \mathrm{~m} / \mathrm{s}$. At catheterization, this patient had severe obstruction at the distal insertion of the conduit and no gradient across the conduit valve. The other patient in this group who has had cardiac catheterization is the one with right ventricular hypertension predicted from the tricuspid regurgitation jet mentioned previously. No other patient in the study group has had a postoperative cardiac catheterization.

\section{DISCUSSION}

With the recent development of improved cryopreservation and surgical techniques, the use of homograft valved conduits has become the preferred method for establishing ventricular-great artery continuity in many centers. ${ }^{16-20}$ The long-term follow-up studies of children who have received fresh, antibiotic-sterilized aortic homograft valves show that $70 \%$ can be expected to be free of conduit obstruction at 15 years after operation. ${ }^{16.17}$ In Kay and Ross's experience, ${ }^{17}$ only $13 \%$ (3 patients) required conduit replacement by 10 years. The obstruction in these children was within the Dacron tube and not at the homograft valve. This type of obstruction can probably be avoided with the use of autologous pericardial tubes or extended pulmonary valve homograft conduits. Little follow-up data are available concerning the fate of cryopreserved aortic or pulmonary homograft valved conduits. ${ }^{19,20}$ In the first report of the intermediate-term fate of cryopreserved aortic homograft valved conduits, Kirklin et al ${ }^{19}$ found $94 \%$ freedom from reoperation at 3.5 years after surgery $(2$ of 147 patients required reoperation). In a preliminary report on the use of cryopreserved pulmonary homografts, Lamberti et $a^{20}$ had 1 of 18 patients who developed severe obstruction and 11 of 18 who developed trivial to mild pulmonary regurgitation. The finding of a majority of patients with pulmonary regurgitation has led to many suggestions for altering surgical techniques 


\begin{tabular}{|c|c|c|c|c|c|c|c|}
\hline \multirow[b]{2}{*}{ Ux } & \multirow{2}{*}{$\begin{array}{l}\text { Age at } \\
\text { Surgery } \\
\text { (yrs) }\end{array}$} & \multicolumn{2}{|c|}{ Conduit } & \multirow{2}{*}{$\begin{array}{l}\text { Location of } \\
\text { Obstruction }\end{array}$} & \multicolumn{2}{|c|}{ Velocity $(\mathrm{m} / \mathrm{s})$ and Gradient $(\mathrm{mm} \mathrm{Hg})$} & \multirow[b]{2}{*}{ Regurgitation } \\
\hline & & Type & Position & & Across Obstruction & Across Valve & \\
\hline Truncus & 0.08 & Pul & Pul & Proximal & $3.2(41)$ & $3.2(-)^{*}$ & $1+$ \\
\hline Truncus & 3.6 & Ao & Pul & Distal & $3.1(38)$ & $1.4(0)$ & 0 \\
\hline Truncus & 5.8 & Pul & Pul & Distal & $4.0(64)$ & $1.5(9)$ & 0 \\
\hline Truncus & 9 & Ao & Pul & Distal & $3.0(36)$ & $1.4(0)$ & $1+$ \\
\hline Truncus & 9 & Pul & Pul & Distal & $3.5(49)$ & $1.2(0)$ & 0 \\
\hline $\mathrm{PA} / \mathrm{VSD}$ & 6.5 & Ao & Pul & Distal & $3.0(36)$ & $1.0(0)$ & $1+$ \\
\hline PA/VSD & 7 & Puil & Pul & Distal & $3.2(41)$ & $2.6(27)$ & 0 \\
\hline PA/VSD & 14 & Ao & Pul & Distal & $\mathrm{RVSP}=74 \mathrm{~mm} \mathrm{Hg}$ & $1.0(0)$ & 0 \\
\hline DORV/PS & 7 & Pul & Pul & Distal & $3.0(36)$ & $1.4(0)$ & 0 \\
\hline
\end{tabular}

in an attempt to limit mechanical causes for valve regurgitation.

To optimize techniques for the preparation and surgical placement of extracardiac conduits, accurate information on the long-term fate of different types of conduits is required. Two-dimensional and Doppler echocardiography provide important noninvasive techniques for the serial assessment of conduit function. The Doppler flow characteristics of normally functioning mechanical and heterograft prosthetic valves have been well described, ${ }^{21-29}$ but the Doppler flow patterns of normally functioning homograft valves have not. In the 71 homograft valves we examined in the immediate postoperative period, the mean peak flow velocity across the valve was $1.6 \pm 0.3 \mathrm{~m} / \mathrm{s}$. The majority of homograft valves $(82 \%)$ had a peak flow velocity $<1.3 \mathrm{~m} / \mathrm{s}$ and no valve had a peak velocity $>2.6 \mathrm{~m} / \mathrm{s}$. For the Hancock porcine valve in the aortic position, the mean peak flow velocity has been reported to be 2.0 to $2.6 \mathrm{~m} / \mathrm{s}$ (range 1.8 to 3.6$){ }^{26,29}$ For the St. Jude mechanical valve in the aortic position, peak velocities ranged from 1.0 to 3.9 $\mathrm{m} / \mathrm{s}$ (mean $2.3 \pm 0.6$ ) in 1 report. ${ }^{29}$ Comparable peak velocities have been reported for the Bjork-Shiley valve in the aortic position (peak velocity $2.6 \pm 0.5 \mathrm{~m} / \mathrm{s}$, range 1.8 to 3.0$).^{29}$ Compared with heterograft tissue valves and mechanical valves in the aortic position, homograft valves in the aortic and pulmonary position appear to have better flow hemodynamics.

In the immediate postoperative period, $62 \%$ of homograft valves had mild regurgitation and $3 \%$ had moderate regurgitation. A comparable incidence of regurgitation has been reported by Panidis et $\mathrm{al}^{29}$ in normallyfunctioning porcinc (44\%), St. Jude (58\%) and Bjork-Shiley (62\%) valves in the aortic position. Thus, in tissue or mechanical valves, regurgitation is usually common, hemodynamically insignificant and clinically unsuspected. ${ }^{26-29}$

Of the 38 patients who had an intermediate followup examination, $66 \%$ had mild and $8 \%$ had moderate homograft valve regurgitation. Although these incidences were similar to those found in the immediate postoperative period, there were changes in the amount of regurgitation in 16 patients. Progression of the amount of regurgitation occurred in 11 patients $(8$ went from 0 to $1+, 1$ from 0 to $2+$ and 2 from $1+$ to $2+$ ). Only 3 patients $(8 \%)$, however, progressed to a moderate amount $(2+)$ of regurgitation. Regression of regurgitation occurred in 5 patients ( 1 went from 2 to $1+, 1$ from $2+$ to 0 and 3 from $1+$ to 0 ). Thus, 2 patients $(5 \%)$ had a regression of regurgitation from a moderate amount to trivial or no regurgitation. It is difficult to determine how much of this progression or regression in regurgitation represents a real change and how much is due to variations in the interpretation of the echocardiogram. With the use of combined pulsed, continuouswave and color Doppler techniques, one is unlikely to err in diagnosing the presence or absence of regurgitation; however, assessment of the degree of regurgitation is far more subject to observer variability. We believe that the progression of regurgitation was real in a minimum of 9 patients ( 8 who went from 0 to $1+$ and 1 who went from 0 to $2+$, total of $24 \%$ ), and regression of regurgitation was real in a minimum of 4 patients (1 who went from $2+$ to 0 and 3 who went from $1+$ to 0 , total of $11 \%$ ).

The occurrence and progression of homograft valve regurgitation is worrisome. Lamberti et $\mathrm{al}^{20}$ noted early pulmonary homograft valve regurgitation in $61 \%$ of their patients and progression of regurgitation in $6 \%$ (1 of 18). Predisposing factors to the development and progression of regurgitation were incompletely relieved pulmonary branch stenosis, pulmonary vascular obstructive disease and mechanical distortion of the valve caused by a conduit that was twisted or too small. Attention to mechanical details or predisposing patient factors may lead to techniques for eliminating or reducing the amount of conduit valve regurgitation.

At the intermediate follow-up examination, only 2 of our 38 patients $(5 \%)$ have developed severe homograft valved conduit obstruction, both at the distal conduit insertion. No patient has developed significant stenosis at the homograft valve itself. The incidence and site of obstruction in our series is in agreement with reports from other centers. ${ }^{19,30}$ Predisposing factors for the development of obstruction at the proximal and distal conduit insertions include the length of the conduit necessary for the repair as well as the age of the child at the time of surgery; ${ }^{19,30}$ thus, very young infants undergoing 
primary repair of truncus arteriosus are particularly prone to development of conduit obstruction.

Acknowledgment: We thank Steven Spillan and Kathy Chmielewski for editorial assistance in the preparation of this manuscript.

\section{REFERENCES}

1. Ross DN, Somerville J. Correction of pulmonary atresia with a homograft aortic valve. Lancet 1966:2:1446-1447.

2. Park SC. Neches WH, Lenox CC, Zuberbuhler JR, Bahnson HT. Massive calcification and obstruction in a homograft after the Rastelli procedure for transposition of the great arteries. Am J Cardiol 1973;32:860-864.

3. Moodie DS, Mair DD, Fulton RE, Wallace RB, Danielson GK, McGoon DC Aortic homograft obstruction. J Thorac Cardiovasc Surg 1976;72:553-56I. 4. Bowman FO Jr, Hancock WD, Malm JR. A valve-containing Dacron prosthesis: its use in restoring pulmonary artery-right ventricular continuity. Arch Surg 1973;107:724-728.

5. Bailey WW, Kirklin JW, Bargeron LM Jr, Pacifico AD, Kouchoukos NT. Late results with synthetic valved external conduits from venous ventricle to pulmonary arteries. Circulation 1977;56(suppl II):II-73-II-79.

6. Ciaravella JM Jr, McGoon DC, Danielson GK, Wallace RB, Mair DD. Experience with the extracardiac conduit. $J$ Thorac Cardiovasc Surg 1979; 78:920-930

7. Norwood WI, Freed MD, Rocchini AP, Bernhard WF, Castenada AR. Experience with valved conduits for repair of congenital cardiac lesions. Ann Tharac Surg 1977;24:223-232.

8. Bissett GS III, Schwartz DC, Benzing G III, Helmsworth JA, Schreiber JT, Kaplan S. Late results of reconstruction of right ventricular outflow tract with porcine xenografts in children. Ann Thorac Surg 1981;31:437-443.

9. Agarwal KC, Edwards WD, Feldt RH, Danielson GK, Puga FJ, McGoon DC. Clinicopathological correlates of obstructed right-sided porcine valved extracardiac conduits. I Thorac Cardiovase Surg 1981:81:591-601.

10. Schaff HV, DiDonato RM, Danielson GK. Reoperation for obstructed pulmonary ventricle-pulmonary artery conduits: early and late results. $J$ Thorac Cardiovasc Surg 1984;88:334-343.

11. Moore CH, Martelli $B$, Ross DN. Reconstruction of right ventricular outflow tract with a valved conduit in 75 cases of congenital heart disease. $J$ Thorac Cardiovasc Surg 1976;71:11-19.

12. Shabbo FP, Wain WH, Ross DN. Right ventricular outflow reconstruction with aortic homograft conduit: analysis of the long-term results. Thorac Cardiovase Surg 1980;28:2I-25.

13. Al-Janabi N, Ross DN. Enhanced viability of fresh aortic homografts stored in nutrient medium. Cardiovasc Res 1973,7:817-822.
14. Yacoub M, Kittle CF. Sterilization of valve homografts by antibiotic solution. Circulation 1970:41 (suppl In):II-29-II-31.

15. DiCarlo D, de Leval MR, Stark J. "Fresh," antibiotic-sterilized aortic homografts in extracardiac valved conduits: long-term results. Thorac Cardiovasc Surg 1984;32:10-14.

16. Fontan F, Choussat A, Deville C, Coutremepuich C, Coupillaud J, Vosa C. Aortic valve homografts in the surgical treatment of complex cardiac malformations. $J$ Thorac Cardiovasc Surg 1984;87:649-657.

17. Kay PH, Ross DN. Fifteen years' experience with the aortic homograft: the conduit of choice for right ventricular outflow reconstruction. Ann Thorac Surg 1985:40:360-364

18. Kirklin JW, Barratt-Boyes BG. Cardiac Surgery. New York: Wiley, $1986: 800$

19. Kirklin JW, Blackstone EH, Maehara T, Pacifico AD, Kirklin JK, Pollock S, Stewart RW. Intermediate-term fate of cryopreserved allograft and xenograft valved conduits. Ann Thorac Surg 1987;44:598-606.

20. Lamberti JJ, Angell WW, Waldman JD, Grehl TM, George L, Matthewson JW, Kirkpatrick SE, Spicer R, Thomson D. The cryopreserved homograft valve in the pulmonary position: early results and technical considerations. J Cardiac Surg 1988;3:247-251.

21. Holen J, Simonson S, Frysaker T. An ultrasound Doppler technique for the noninvasive determination of the pressure gradient in the Bjork-Shiley mitral valve. Circulation 1979;59:436-442.

22. Ramirez ML, Wong M, Sadler N, Shah PM. Doppler evaluation of 106 bioprosthetic and mechanical aortic valves (abstr). JACC 1985;5:527.

23. Hatle L, Angelsen B. Doppler Ultrasound in Cardiology: Physical Principles and Clinical Applications. Second ed. Philadelphia: Lea and Febiger, 1985:188196

24. Gross CM, Wann LS. Doppler echocardiographic diagnosis of porcine bioprosthetic cardiac valve malfunction. Am J Cardiol 1984:53:1 203-1205.

25. Kotler MN, Mintz GS, Panidis IP, Morganroth J, Segal BL, Ross J. Noninvasive evaluation of normal and abnormal prosthetic valve function. $J A C C$ $1983 ; 2: 151-173$.

26. Sagar KB, Wann LS, Paulsen WHJ, Romhilt DW. Doppler echocardiographic evaluation of Hancock and Bjork-Shiley prosthetic valves. JACC 1986;7:681-687.

27. Ferrara RP, Labovitz AJ, Wiens RD, Kennedy HL, Williams GA. Prosthetic mitral regurgitation detected by Doppler echocardiography. Am J Cardiol 1985;55:229-230.

28. Williams GA, Labovitz AJ. Doppler hemodynamic evaluation of prosthetic (Starr-Edwards and Bjork-Shiley) and bioprosthetic (Hancock and CarpentierEdwards) cardiac valves. Am J Cardiol 1985;56:325-332.

29. Panidis IP, Ross J, Mintz GS. Normal and abnormal prosthetic valve function as assessed by Doppler echocardiography. JACC 1986:8:317-326.

30. Bull C, Macartney FJ, Horvath P, Almeida R, Merrill W, Douglas J, Taylor JFN, de Leval MR, Stark J. Evaluation of long-term results of homograft and heterograft valves in extracardiac conduits. $J$ Thorac Cardiovasc Surg 1987; 94:12-19. 